\title{
PENGUKURAN TINGKAT KESIAPAN IMPLEMENTASI E-LEARNING (E-LEARNING READINESS) DI SMA N 2 SINGARAJA MENGGUNAKAN MODEL CHAPNICK
}

\author{
R. Ramadan'), I M. A. Pradnyana2), P W. A. Suyasa' ${ }^{3)}$ \\ ${ }^{1}$ Fakultas Teknik dan Kejuruan, Universitas Pendidikan Ganesha \\ Email: rizkyramadhan12377@gmail.com¹ , ardwi.pradnyana@undiksha.ac.id², arta.suyasa@undiksha.ac.id ${ }^{3}$
}

\begin{abstract}
ABSTRAK
Tujuan dari penelitian ini adalah untuk mengetahui kesiapan penerapan e-learning di SMA N 2 Singaraja dengan menggunakan model Chapnick, dengan menggunakan 8 variabel untuk mengetahui kesiapan guru, siswa, sekolah dan menunjukan faktorfaktor yang siap dan tidak siap dalam penerapan e-learning. Sampel dalam penelitian ini terdiri dari 30 responden guru dan 90 responden siswa dan menggunakan proportionate starafied random sampling sebagai teknik pengambilan data. Hasil penelitian ini menunjukan guru memperoleh skor $\bar{x}=3,35<=3,41$ termasuk dalam katagori tidak siap dan membutuhkan sdikit peningkatan, siswa memperoleh skor $\bar{x}=3,20<\bar{x}=3,41$ termasuk dalam katagori tidak siap dan membutuhkan sdikit peningkatan dan sekolah memperoleh skor $\bar{x}=3,27<\bar{x}=3,41$ termasuk dalam katagori tidak siap dan membutuhkan sdikit peningkatan. Ada 6 faktor yang masih perlu peningkatan dan perbaikan yaitu psychological readiness, sociological readiness, financial readiness, technological skill readiness, equipment readiness, content readiness. Peningkatan ini bertujuan agar penerapan e-learning dalam proses pembelajaran di SMA N 2 Singaraja dapat berjalan dengan baik sehingga hasil belajar siswa dapat meningkat.
\end{abstract}

Kata kunci: Implementasi E-learning, Kesiapan, E-learning Readiness, Chapnick.

\begin{abstract}
The purpose of this study was to determine the readiness of the application of elearning in SMA N 2 Singaraja using the Chapnick model, using 8 variables to determine the readiness of teachers, students, schools and to show factors that were ready and not ready for the application of e-learning. The sample in this study consisted of 30 teacher respondents and 90 student respondents and used a proportionate standard random sampling as a data collection technique. The results of this study show that the teacher obtained a score $\bar{x}=3.35<\bar{x}=3.41$ included in the category not ready and requires a little increase, students get a score $\bar{x}=3.20<\bar{x}=3.41$ included in the category not ready and need a little increase and the school gets score $\bar{x}=3.27<\bar{x}=3.41$ included in the category not ready and requires a slight increase. There are 6 factors that still need improvement and improvement, namely psychological readiness, sociological readiness, financial readiness, technological skill readiness, equipment readiness, content readiness. This increase aims that the application of e-learning in the learning process in SMA N 2 Singaraja can run well so that student learning outcomes can increase.
\end{abstract}

Keywords : Implementation of E-learning, Readiness, E-learning Readiness, Chapnick.

\section{PENDAHULUAN}

Perkembangan ilmu pengetahuan dan teknologi (IPTEK) membawa manusia ke era persaingan global yang sangat ketat dan jika tidak ingin tersingkir dari penerapan tersebut, maka kualitas sumber daya manusia (SDM) harus terus ditingkatkan. Untuk meningkatkan kualitas sumber daya manusia salah satu caranya adalah melalui jalur pendidikan. Pendidikan merupakan usaha secara sadar dan terencana untuk mewujudkan secara aktif mengembangkan potensi dirinya untuk memiliki kekuatan spiritual, keagamaan, pengendalian diri, kebiasaan, kecerdasan dan keterampilan yang diperlukan bagi dirinya, masyarakat, bangsa dan Negara. Di era persaingan globalisasi ini tidak dapat terlepas dari salah satu bidang yaitu Teknologi Informasi dan Komunikasi (TIK). Istilah TIK merupakan istilah 
deskriptif yang sangat luas untuk setiap perangkat keras atau perangkat lunak, atau bahkan setiap kegiatan yang berhubungan dengan penggunaan komputer untuk pembuatan, penyimpanan, pengiriman dan penerimaan informasi dalam format elektronik. Salah satu pemanfaatan TIK adalah teknologi komputer dengan menggunakan internet. Teknologi internet menjadi suatu solusi dalam mengatasi masalah kelambanan proses. Pemerintah Indonesia melalui Peraturan Pemerintahan Republik Indonesia [1] yang bertujuan meningkatkan perluasan dan pemerataan akses pendidikan, serta meningkatkan mutu dan relevansi pendidikan berupaya untuk meratakan kegiatan belajar jarak jauh di seluruh pelosok Indonesia. Dalam proses pembelajaran jarak jauh ini juga bisa memberikan harapan untuk peningkatan mutu pindidikan di Indonesia. Penerapan internet di bidang pendidikan paling jelas implementasinya sekarang adalah penggunaan e-learning untuk penyebaran informasi dan berkomunikasi. Konsep e-learning inilah merupakan sistem pendidikan yang berbasis internet yang diterima dengan baik dan banyak digunakan saat ini. Dengan adanya e-learning para siswa atau guru dapat menaruh materi pembelajaran, member tugas, mengumpulkan tugas maupun kuis untuk evaluasi, serta dapat berkomunikasi dengan siswa. Dengan demikian aktifitas pembelajaran dapat dilakukan kapan saja dan dimana saja.

Penerapan e-learning di Provinsi Bali telah mendapat dukungan oleh pemerintah pusat, Menteri Pendidikan dan Kebudayaan RI menjadikan Bali sebagai sekolah model untuk kelas maya. Pemerintah Provinsi Bali pun mengatakan pihaknya telah menggelar rapat koordinasi pelaksanaan elearning di Dinas Pendidikan Provinsi Bali. SMA dan SMK Negeri serta swasta merespons positif dan segera diimplementasikan lebih luas. Salah satu sekolah di Buleleng yang mendapatkan pelatihan elearning Jejak Bali adalah SMA 2 Singaraja. Berdasarkan hasil observasi di SMA Negeri 2 Singaraja, proses belajar mengajar di SMA Negeri 2 Singaraja telah menggunakan peralatan elektronik. Penggunaan peralatan elektronik merupakan dasar dari penerapan e-learning di suatu sekolah. SMA Negeri 2 Singaraja memiliki fasilitas LCD proyektor untuk tiap kelas yang digunakan untuk para siswa dan guru sebagai alat tambahan dalam proses belajar mengajar seperti memberikan materi oleh guru kepada siswa dan sebagai media siswa untuk melakukan presentasi. SMA Negeri 2 Singaraja sebagian besar telah terkoneksi dengan jaringan internet, yaitu di ruang kepala sekolah, ruang guru, ruang tata usaha dan laboratorium komputer. Bahkan saat ini SMA Negeri 2 Singaraja telah dibangun sistem jaringan nirkabel (wireless) sehingga memudahkan bagi guru dan siswa untuk mendapatkan akses internet secara bebas dan mudah. SMA Negeri 2 Singaraja telah memiliki situs resmi yaitu dengan nama domain www.smanda-singaraja.sch.id. Sangat disayangkan situs ini hanya menampilkan pengumuman-pengumuman dari sekolah tidak di sertai media untuk pembelajaran seperti e-learning. Berdasarkan hasil wawancara dengan kepala sekolah yaitu Bapak Drs. I Made Arya Kartawan, M.Pd, di SMA N 2 Singaraja mewajibkan seluruh guru untuk melakukan proses belajar mengajar menggunakan e-learning Jejak Bali, tetapi sebagian besar guru masih melakukan proses belajar mengajar dengan menggunakan metode tatap muka dan hanya $5 \%$ guru melakukan pembelajaran berbasis online dengan memanfaatkan e-learning. Diketahui bahwa permasalahan sebagian besar guru SMA Negeri 2 Singaraja adalah pada kemampuan menggunakan perangkat teknologi, kurangnya rasa sosialisasi antara guru dan guru untuk berkomunikasi tentang pembelajaran berbasis e-learning, dan guru-guru di SMA N 2 Singaraja kurang berinisiatif untuk memanfaatkan pembelajaran berbasis e-learning yang diterapkan di SMA 2 Singaraja. Selain itu dari segi fasilitas meskipun sekolah sudah menyediakan fasilitas jaringan internet, tetapi ada beberapa access point yang tidak berkerja atau rusak. Kemudian dari sumber daya manusia, SMA N 2 Singaraja tidak mempunyai tenaga khusus IT. Sebelumnya SMA N 2 Singaraja pernah menerapakan e-learning Schoology dan Quiper, tetapi dalam penerapan tersebut terjadi kegagalan. Dari pihak kepala sekolah sendiri e-learning Jejak Bali diharapkan tidak terjadi kegagalan seperti e-learning sebelumnya, karena pemerintah Provinsi Bali mewajibkan seluruh guru di Bali harus melaksanakan pembelajaran berbasis e-learning, khususnya kelas maya Jejak Bali.

Berdasarkan permasalahan, serta keadaan yang diuraikan diatas dan belum adanya penelitian untuk menguji kesiapan penerapan e-learning di SMA N 2 Singaraja, maka dari itu perlu diadakan penelitian untuk mengetahui tingkat kesiapan penerapan e-learning di SMA $\mathrm{N} 2$ Singaraja menggunakan e-learning readiness menggunakan model chapnick.

E-learning sebagai media pembelajaran masih tergolong hal baru, dan e-learning sebagian besar digunakan oleh perguruan tinggi. Hal tersebut mengakibatkan penelitian tentang penerapan elearning pada jenjang SMA masih sangat sedikit.

Model e-learning readiness chapnick menggunakan delapan faktor readiness untuk mengukur E-learning Readiness. Model chapnick akan memberikan hasil berupa skor yang dapat menentukan peringkat kesiapan e-learning suatu sekolah. Model ini dipilih karena dapat digunakan sebelum penerapan e-learning dalam proses pembelajaran. Selain itu E-learning Readiness model Chapnick 
dapat digunakan secara terus menerus untuk menjaga keberlangsungan program penerapan elearning dalam proses pembelajaran. Model ini hanya memfokuskan pada aspek institusi dalam hal ini adalah guru dan siswa.

Penerapan e-learning yang tidak matang, akan memberikan peluang yang cukup besar akan kegagalan penerapan e-learning tersebut. Kegagalan penerapan e-learning akan menyebabkan kerugian yang cukup besar, baik kerugian material (financial), waktu dan sumber daya pendukung lainnya. Dalam menyebutkan bahwa terdapat 33 penyebab kegagalan e-learning, penyebab kegagalan tersebut dibagi menjadi : Poor alignment to needs, Communication, Lack of implementation skill, Poor Implementation Process, Management Commitment, Scalabillity, Support, Technology. Untuk meminimalisir kegegalan tersebut, maka perlu dilakukan evaluasi secara menyeluruh terhadap penerapan e-learning. Untuk melakukan evaluasi tersebut diperlukan suatu metode atau model evaluasi penerapan e-learning dalam proses pembelajaran. Evaluasi yang dilakukan adalah evaluasi untuk mengetahui tingkat kesiapan (e-readiness) dan evaluasi tingkat kematangan (maturity) dari penerapan e-learning tersebut.

\section{METODE}

1. Jenis Penelitian

Jenis penelitian e-learning readiness adalah penelitian survei berbasis pengguna, sedangkan metodenya adalah deskriptif analitis. Menurut [2] penelitian deskriptif yaitu, penelitian yang dilakukan untuk mengetahui nilai variabel mandiri, baik satu variabel atau lebih (independen) tanpa membuat perbandingan, atau menghubungkan dengan variabel yang lain. Berdasarkan teori tersebut, penelitian deskriptif kuantitatif, merupakan data yang diperoleh dari sampel populasi penelitian dianalisis sesuai dengan metode statistik yang digunakan. Penelitian deskriptif dalam penelitian ini dimaksudkan untuk mendapatkan gambaran mengenai kesiapan SMA N 2 Singaraja dalam penerapan e-learning.

2. Lokasi dan Waktu Penelitian

Lokasi penelitian merupakan tempat dimana penelitian akan dilakukan. Penelitian ini akan dilaksanakan di SMA N 2 Singaraja. Subjek yang akan diteliti adalah guru dan siswa kelas $X$ dan kelas IX di SMA N 2 Singaraja..

3. Prosedur Penelitian

Prosedur penelitian merupakan langkah-langkah yang ditempuh dalam melakukan suatu penelitian, untuk mendapatkan infomasi yang dapat menjawab pertanyaan peneliti. Prosedur penelitian dilaksanakan untuk dapat mengungkap secara tuntas terkait permasalahan yang diajukan dalam penelitian. Adapun penelitian ini adalah sebagai berikut

Melakukan observasi ke lolasi penelitian dengan melakukan wawancara ke kepala sekolah kemudian lanjut ke tahap mengidentifikasi dan merumuskan dan membatasi permasalahan, selanjutnya melakukan kajian pustaka dan kajian teori yang berkaitan dengan permasalahan, kemudian mendesain metode penelitian yang akan digunakan dalam hal ini adalah menentukan populasi, sampel, teknik sampling, teknik pengumpulan data, instrumen penelitian dan analisis data. Sebelum penyebaran kuisioner dilakukan pada kelompok sampel, peneliti melakukan melakukan uji coba kuisioner, dengan menyebarkan kuisioner pada kelompok kecil. Hal ini dilakukan untuk mendapatkan gambaran apakah instrumen sudah dimengerti oleh responden. Selanjutnya peneliti melakukan pengambilan data dengan menyebarkan kuisioner pada sampel peneliti. Selanjutnya peneliti melakukan pengolahan data. Hasil kuisioner dalam penelitian ini dianalisis secara kuantitatif untuk kemudian dideskripsikan secara kualitatif. Dan tahap akhir dari penelitian ini peneliti membuat laporan penelitian. Skema dari prosedur penelitian dapat disajikan pada gambar 1 . 


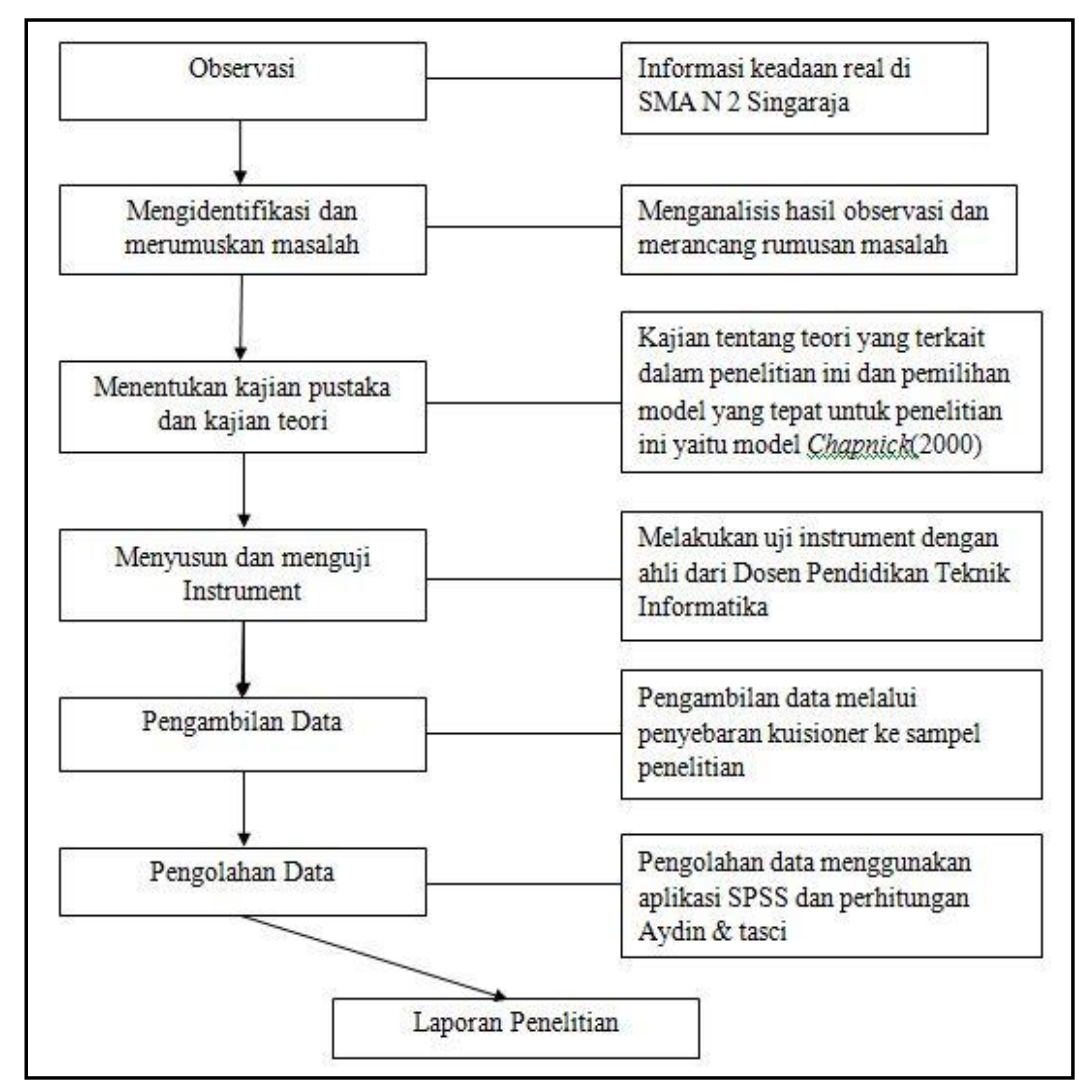

4. Penelitian Terkait

Gambar 1. Prosedur Penelitian

Penelitian tentang readiness telah dilakukan di beberapa institusi. Peneliti menganalisis beberapa penelitian terkait yang sebelumnya sudah diteliti seperti yang dilakukan di SMK Yogyakarta oleh [3] yang berjudul "Tingkat Kesiapan (Readiness) model ELR dengan mengelompokkan kesiapan ke dalam delapan kategori kesiapan. Selanjutnya di tahun yang sama dilakukan oleh [4], penelitian yang berjudul "Pengukuran Tingkat Kesiapan E-Learning (E-Learning Readiness)" menggunakan framework penelitian dengan enam komponen utama yaitu Human Resource, Kultur Organisasi, Teknologi, Kebijakan, Keadaan Keuangan Organisasi dan Infrastruktur. Penelitian selanjutnya adalah penelitian "Kajian Implementasi E-Learning Berdasarkan Tingkat Kesiapan Peserta E-Learning" oleh [5], penelitian ini menggunakan empat variabel yang diasumsikan memiliki pengaruh terhadap kesiapan peserta e-learning yaitu akses teknologi (TA), keahlian komputer dan internet (COS), motivasi dan gaya belajar (LS). Selanjutnya penelitian [6] "Analisis Pengukuran Tingkat Kesiapan Knowledge Management: Studi Kasus Pusat Pengolahan Data dan Informasi Badan Koordinasi Penanaman Modal" Evaluasi sistem yang ada di Pusdatin tersebut meliputi budaya organisasi, struktur organisasi, infrastruktur teknologi informasi, pengetahuan umum, dan lingkungan fisik. Di tahun selanjutnya ada penelitian dari [7] yang berjudul "Analisis kesiapan implementasi e-learning menggunakan e-learning readiness model" evaluasi ini menggunakan 4 faktor yaitu teknologi, inovasi, manusia, dan pengembangan diri.

Dari beberapa penelitian terkait yang pernah dilakukan sebelumnya, model yang peneliti dapat adopsi yaitu model ELR Chapnick, Model Chapnick akan memberikan hasil berupa skor yang dapat menentukan peringkat kesiapan e-learning suatu sekolah. Model ini dipilih karena dapat digunakan sebelum dan sesudah penerapan e-learning dalam proses pembelajaran. Selain itu Model Chapnick dapat digunakan secara terus menerus untuk menjaga keberlangsungan program penerapan $e-$ learning dalam proses pembelajaran. Model ini digunakan karena sangat cocok dengan permasalahan yang terjadi untuk menguji kesiapan penerapan e-learning di SMA N 2 Singaraja. Model ini telah digunakan secara luas (best practice) dan sangat sesuai untuk kasus implementasi $e$ learning di negara berkembang termasuk Indonesia.

5. Sampel Penelitian 
Menurut [8] yang menyatakan bahwa untuk penelitian yang menggunakan analisis data statistik, ukuran sampel paling minimum adalah 30. Maka peneliti menggunakan 30 sampel dari jumlah populasi guru yang ada di SMA N 2 Singaraja.

Jumlah sampel siswa yang digunakan dalam penelitian ini menggunakan teknik Slovin menurut [2]. Adapun penelitian ini menggunakan rumus Slovin karena dalam penarikan sampel, jumlahnya harus representative agar hasil penelitian dapat digeneralisasikan dan perhitungannya pun tidak memerlukan tabel jumlah sampel, namun dapat dilakukan dengan rumus dan perhitungan sederhana. Rumus Slovin untuk menentukan sampel adalah sebagai berikut :

$$
n=\frac{N}{1+N(e)^{2}}
$$

Keterangan:

$\mathrm{n}=$ Ukuran sampel/jumlah responden

$\mathrm{N}=$ Ukuran populasi

$\mathrm{e}=$ Presentase kelonggaran ketelitian kesalahan pengambilan sampel yang masih bisa ditolerir; $\mathrm{e}=0,1$

Dalam rumus Slovin ada ketentuan sebagai berikut:

Nilai e $=0,1(10 \%)$ untuk populasi dalam jumlah besar

Nilai $e=0,2(20 \%)$ untuk populasi dalam jumlah kecil

6. Teknik Pengumpulan Data :

Pengumpulan data adalah cara yang digunakan oleh peneliti untuk mengumpulkan data bagi penelitiannya. Sesuai dengan jenis penelitian dan tujuan yang ingin dicapai dalam penelitian ini

[9]. Teknik pengumpulan data yang digunakan dalam penelitian ini adalah :

a. Dokumentasi

Metode dokumentasi yaitu salah satu cara mencari data mengenai hal-hal atau variabel yang berupa catatan, transkrip, buku, surat kabar, majalah, prasasti, dan sebagiannya. Pada penelitian ini, peneliti menggunakan dokumentasi sebagai sarana untuk mendapatkan data yang diinginkan. Dokumentasi dalam penelitian ini berupa data guru dan data siswa yang diperoleh dari wawancara, dan kuisioner.

b. Kuisioner

Pengukuran variabel dilakukan dengan menggunakan skala Likert. Responden diminta untuk memilih salah satu dari 5 jawaban yang digunakan untuk mengukur setiap indikator. Kuisioner setelah disusun, sebelum disebarkan pada kondisi sebenarnya terlebih dahulu dilakukan uji coba untuk mengetahui reliabilitas dan validitasnya. Setelah dinilai cukup reliabel dan valid maka seterusnya kuisioner disebarkan pada semua responden. Selanjutnya untuk mempermudah pengukuran, data kualitatif diubah menjadi data kuantitatif dengan memberikan nilai atau skor pada masing-masing jawaban. Nilai atau bobot nilai dari jawaban responden disajikan pada Tabel 1.

Tabel 1. Bobot Nilai Jawaban Responden

\begin{tabular}{l|ll}
\hline \multirow{2}{*}{\multicolumn{1}{c}{ Alternatif Jawaban }} & \multicolumn{2}{|l}{ Bobot Nilai Untuk Pernyataan } \\
\cline { 2 - 3 } & Positif & Negatif \\
\hline Sangat setuju & 5 & 1 \\
Setuju & 4 & 2 \\
Kurang setuju & 3 & 3 \\
Tidak setuju & 2 & 4 \\
Sangat Tidak Setuju & 1 & 5 \\
\hline
\end{tabular}

7. Jenis Data

Jenis data dalam penelitian ini terdiri dari data kualitatif dan kuantitatif.

a. Data kualitatif dalam penelitian ini adalah kutipan atau referensi dari jurnal penelitian yang terkait, artikel dan buku

b. Data kuantitatif dalam penelitian ini adalah hasil yang didapatkan dari penyebaran kusioner.

8. Sumber Data 
Sumber data dalam penelitian ini terdiri dari data primer dan data skunder.

a. Data primer dalam penelitian ini adalah hasil survey terhadap terhadap responden dengan menggunakan instrumen yang tertera pada angket guru dan siswa

b. Data skunder dalam penelitian ini didapatkan dari artikel, buku dan literature lainnya yang relevan dengan penelitian.

9. Instrumen Penelitian

Dalam penelitian ini, instrumen yang digunakan adalah dalam bentuk angket guru dan angket siswa.

10. Uji Coba Instrumen

Pada uji coba instrumen dilakukan pengujian terhadap item-item pernyataan yang terdapat pada kuisioner yaitu menggunakan uji gregory, uji validitas dan reliabilitas.

11. Teknik Analisis Data

Setelah semua data terkumpul, dilakukan analisis menggunakan model ELR Aydin \& Tasci (2005) dalam [10]. Adapun analisisnya adalah sebagai berikut.

Skor yang digunakan dalam lembar penilaian yaitu $5,4,3,2$, dan 1 untuk tiap pertanyaan. Setelah lembar penilaian diisi oleh responden akan diperoleh skor total, elanjutnya dihitung ratarata akhir dengan menggunakan rumus,

$$
\bar{x}=\frac{\sum x}{n}
$$

$$
\begin{array}{ll}
\text { Keterangan : } & \mathrm{x}=\text { rata-rata akhir } \\
& \Sigma \mathrm{x}=\text { jumlah skor total } \\
& \mathrm{n}=\text { jumlah responden }
\end{array}
$$

Skor rata-rata dari setiap pertanyaan, skor rata-rata pertanyaan untuk satu faktor yang sama dan skor rata-rata total dari semua pertanyaan akan dinilai menggunakan skala penilaian model ELR Aydin \& Tasci. Skala penilaian tersebut berupa empat kategori yaitu siap dan penerapan elearning dapat dilanjutkan, siap tetapi membutuhkan sedikit peningkatan, tidak siap dan membutuhkan sedikit peningkatan, serta tidak siap dan membutuhkan banyak peningkatan. Skala penilaian tersebut ditunjukkan pada Gambar 2.

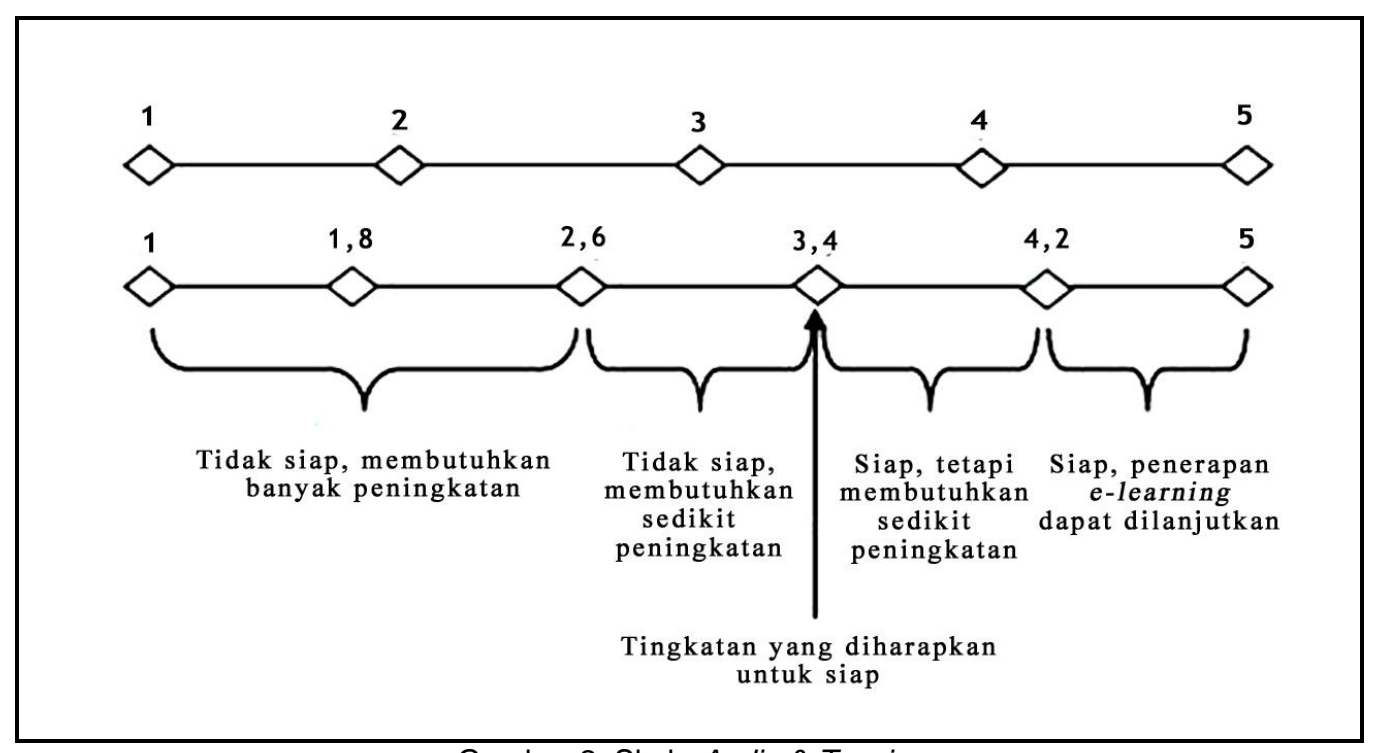

Gambar 2. Skala Aydin \& Tasci

Skor rata-rata 3,41 merupakan skor minimal untuk tingkat kesiapan penerapan e-learning, sehingga $x$ elr $=3,41$ yang berarti skor rata-rata dari tiap pertanyaan, skor rata-rata pertanyaan untuk satu faktor yang sama dan skor rata-rata total dari semua pertanyaan harus $x<=x$ elr untuk dapat dianggap siap dalam penerapan e-learning. 


\section{HASIL DAN PEMBAHASAN}

Penelitain ini dimulai dari tanggal 20 Mei 2019 sampai dengan 15 Juni 2019. Pengambilan data dilakukan dengan memberikan kuisioner kepada Guru dan Siswa di SMA N 2 Singaraja dengan sampel 90 responden siswa dan 30 responden guru. Penelitian ini dilakukan dengan cara mendatangi langsung lokasi penelitian.

Penelitian ini menggunakan kuesioner yang berisi 38 pertanyaan-pertanyaan berdasarkan model chapnick untuk delapan faktor, yaitu Psychological readiness, Sociological readiness, Environmental readiness, Human resource readiness, Financial readiness, Technological skill (aptitude) readiness, Equipment eadiness, Content readiness.

1. Hasil Uji Gregory

Perhitungan uji validitas isi dilakukan dengan formula gregory dengan melibatkab 2 orang pakar. Hasil penilaian dari kedua pakar untuk angket guru adalah 27 jawaban dinyatakan relevan jadi koefisien validitas isi instrumen yang diuji coba adalah 0.71 yang berkategori tinggi. Hasil penilaian dari kedua pakar untuk angket guru adalah 32 jawaban dinyatakan relevan jadi koefisien validitas isi instrumen yang diuji coba adalah 0.84 yang berkategori sangat tinggi. Untuk instrumen yang dinilai tidak relevan telah diperbaiki sehingga relevan dan semua instrumen dapat diuji cobakan.

2. Hasil Uji Validitas

Pengujian validitas untuk instrumen menggunakan rumus korelasi Pearson Product Moment. Dalam penelitian ini kuisioner telah diujicobakan ke 20 responden guru dan 30 responden siswa diluar sampel penelitian. Hasil perhitungan menggunakan Microsoft Excel 2016 dan Aplikasi SPSS 20. Butir instrumen yang diuji cobakan berjumlah 38 butir, 18 dari kuisioner guru dan 13 kuisioner siswa dinyatakan tidak valid. Oleh karena itu semua pertanyaan yang memiliki korelasi dibawah 0,444 untuk guru dan dibawah 0,361 untuk siswa dinyatakan tidak valid [2] kemudian pertanyaan yang tidak valid, tidak diperbaiki dan tidak diuji coba kembali melainkan langsung dihilangkan dikarenakan semua indikator yang digunakan sudah ada pertanyaan yang mewakili sebanyak 1-3 butir pertanyaan.

3. Hasil Uji Reliabilitas

Uji reliabilitas dilakukan untuk menguji derajat konsistensi atau stabilitas instrumen dalam interval tertentu. Perhitungan uji reliabilitas menggunakan aplikasi SPSS 20. Berdasarkan dari 38 butir pernyataan yang di uji cobakan kepada 20 responden guru dan dari 38 butir pernyataan yang diujicobakan kepada 30 responden siswa. Kriteria Tinggi Rendahnya Nilai Koefesien Reliabilitas, nilai crocnbach alpha pada instrumen guru berkategori sangat tinggi yaitu $0,8 \leq 0,822<1$. Dan nilai crocnbach alpha pada instrumen siswa berkategori sangat tinggi yaitu $0,8 \leq 0,883<1$.

4. Hasil Uji Aydin \& Tasci

Data berupa hasil angket yang diperoleh dari responden sebanyak 30 guru dan 90 siswa, kemudian dilakukan analisis dengan menggunakan model ELR Aydin \& Tasci (2005). Angket penelitian ini memiliki 20 pernyataan untuk guru dan 25 pernyataan untuk siswa. Setelah melakukan analisis data, peneliti memperoleh data guru dan siswa sebagai berikut :

Tabel 2. Statistik Guru dan siswa

\begin{tabular}{lrrr}
\hline Faktor & Nilai Guru & Nilai Siswa & \multicolumn{1}{c}{ Skor ELR } \\
\hline - Psycological Readiness & 3.28 & 3.34 & 3.31 \\
- Sociological Readiness & 3.11 & 3.53 & 3.32 \\
- Environmental Readiness & 3.62 & 3.37 & 3.49 \\
- Human Resource Readiness & 3.52 & 3.42 & 3.47 \\
- Financial Readiness & 3.43 & 3.02 & 3.22 \\
- Technological Skill Readiness & 3.13 & 3.37 & 3.25 \\
- Equipment Readiness & 3.17 & 2.82 & 2.99 \\
- Content Readiness & 3.55 & 2.78 & 3.16 \\
Total & 3.35 & 3.20 & 3.27 \\
\hline
\end{tabular}

Hasil penelitian menunjukan bahwa skor ELR guru adalah $\mathrm{x}=3,35$. Berdasarkan rentang nilai dan katagori yang dikemukakan oleh Aydin dan Tasci (2005) untuk guru termasuk dalam katagori tidak siap dan membutuhkan sedikit peningkatan. Ada 4 faktor yang menunjukan kesiapan tetapi masih membutuhkan sedikit peningkatan yaitu faktor environmental readiness yang memperoleh skor 
$x=3,62$, faktor human resource readiness yang memperoleh skor $x=3,52$, faktor financial readiness yang memperoleh skor $x=3,43$, faktor content readiness yang memperoleh skor $x=3,55$ dan ada 4 faktor yang menunjukan tidak siap dan membutuhkan sedikit peningkatan yaitu faktor psychological readiness yang memperoleh skor $\mathrm{x}=3,28$, faktor sociological readiness yang memperoleh skor $\mathrm{x}=3,12$, faktor technological skill readiness yang memperoleh skor $\mathrm{x}=3,13$, faktor equipment readiness yang memperoleh skor $x=3,17$. Hasil penelitian menunjukan bahwa skor ELR siswa adalah $x=3,20$. Berdasarkan rentang nilai dan katagori yang dikemukakan oleh Aydin dan Tasci (2005) untuk siswa termasuk dalam katagori tidak siap dan membutuhkan sedikit peningkatan. Ada 2 faktor yang menunjukan kesiapan tetapi masih membutuhkan sedikit peningkatan yaitu faktor sociological readiness yang memperoleh skor $\mathrm{x}=3,53$, faktor human resource readiness yang memperoleh skor $\mathrm{x}=3,42$ dan ada 6 faktor yang menunjukan tidak siap dan membutuhkan sedikit peningkatan yaitu faktor psychological readiness yang memperoleh skor $\mathrm{x}=3,34$, faktor environmental readiness yang memperoleh skor $\mathrm{x}=3,43$ faktor financial readiness yang memperoleh skor $\mathrm{x}=3,37$, faktor technological skill readiness yang memperoleh skor $\mathrm{x}=3,01$, faktor equipment readiness yang memperoleh skor $\mathrm{x}=2,82$, faktor content readiness yang memperoleh skor $\mathrm{x}=2,78$.

Hasil penelitian ini sejalan dengan hasil wawancara yang telah dilakukan oleh peneliti di saat tahap observasi dan melakukan wawacara dengan kepala sekolah di SMA N 2 Singaraja, dalam penelitian ini skor ter rendah untuk guru berada pada faktor sociological readiness yang memperoleh skor $\mathrm{x}=3,11$ termasuk dalam katagori tidak siap dan membutuhkan sedikit peningkatan dan skor tertinggi guru berada pada faktor environmental readiness yang memperoleh skor $\mathrm{x}=3,62$ termasuk dalam katagori siap tetapi membutuhkan sedikit peningkatan. Sedangkan skor ter rendah pada siswa berada pada faktor financial readiness yang memperoleh skor $\mathrm{x}=3,02$ termasuk dalam katagori tidak siap dan membutuhkan sedikit peningkatan dan skor tertinggi guru berada pada faktor sociologikal readiness yang memperoleh skor $\mathrm{x}=3,53$ termasuk dalam katagori siap tetapi membutuhkan sedikit peningkatan. Rekomendasi yang dapat diberikan kepada siswa, guru, dan sekolah yaitu perlunya peningkatan dan perbaikan pada beberapa faktor kesiapan penerapan e-learning, yaitu pada faktor psychological readiness, sociological readiness, financial readiness, technological skill readiness, equipment readiness, content readiness. Peningkatan ini bertujuan agar penerapan e-learning dalam proses pembelajaran di SMA N 2 Singaraja dapat berjalan dengan baik sehingga hasil belajar siswa dapat meningkat.

Berdasarkan hasil skor penilaian ELR dengan model Aydin \& Tasci (2005) pada Tabel 2. Maka dapat diketahui bahwa SMA N 2 Singaraja mempunyai skor ELR 3,27. Hal tersebut menunjukan bahwa SMA N 2 Singaraja tidak siap untuk menerapkan e-learning dan masih membutuhkan sedikit peningkatan dalam faktor psychological readiness yang memperoleh skor $x=3,31$, faktor sociological readiness yang memperoleh skor $x=3,32$, faktor financial readiness yang memperoleh skor $\mathrm{x}=3,22$, faktor technological skill readiness yang memperoleh skor $\mathrm{x}=3,25$, faktor equipment readiness yang memperoleh skor $\mathrm{x}=2,99$, faktor content readiness yang memperoleh skor $\mathrm{x}=3,16$. Sedangkan untuk faktor environmental readiness yang memperoleh skor $\mathrm{x}=3,49$ dan human resource readiness yang memperoleh skor $x=3,47$ menunjukan bahwa SMA N 2 Singaraja termasuk dalam kategori siap tetapi perlu sedikit peningkatan agar penerapan e-learning dapat dilanjutkan.

Berdasarkan perhitungan di atasi menunjukan bahwa ada 6 faktor yang menunjukan tidak siap dan membutuhkan sedikit peningkatan yaitu faktor psychological readiness, faktor sociological readiness, faktor financial readiness, faktor technological skill readiness, faktor equipment readiness, faktor content readiness. Oleh karena itu pihak sekolah dapat melakukan perbaikan - perbaikan sesuai dengan rekomendasi yang diusulkan, antara lain Faktor psychological readiness, sekolah harus bisa merubah cara pandang individu baik guru maupun siswa dengan cara memberikan pengarahan maupun informasi yang lebih dalam mengenai manfaat dan kemudahan menggunakan e-learning dalam proses pembelajaran. Faktor sociological readiness, baik guru maupun siswa diharapkan kedepannya untuk bisa lebih bersosialisasi dan berbagi tentang informasi e-learning, sehingga guru maupun siswa dapat beradaptasi terhadap perubahan / inovasi yang ada pada $e$ learning dan dapat menerapkan perubahan pembelajaran berbasis e-learning agar diterima warga sekolah. Faktor financial readiness, pihak sekolah disarankan untuk memberikan dukungan dana dan membuat rincian anggaran untuk menerapkan e-learning antara lain penambahan infrastruktur jaringan internet, perawatan serta alokasi dana untuk pengelola atau administrator e-learning yang menangani e-learning sehingga e-learning dapat diimplementasikan dengan baik. Faktor technological skill readiness, pihak sekolah diharapkan lebih sering melakukan pelatihan e-learning baik ke guru maupun siswa, agar guru dan siswa bisa lebih mudah dan lancar untuk menggunakan elearning dalam proses pembelajaran. Faktor equipment readiness, pihak sekolah diharapkan lebih memperhatikan lagi mengenai fasilitas-fasilitas seperti access point yang tidak berfungsi, komputer, 
dan beberapa proyektor untuk mendukung keberlangsungannya proses pembelajaran berbasis $e$ learning di sekolah. Faktor content readiness, pihak sekolah diharapkan bisa menambah kontenkonten digital dan memberikan informasi tentang konten-konten digital yang dimiliki di SMA N 2 Singaraja.

\section{SIMPULAN DAN SARAN}

Kesimpulan dari hasil penelitian ini menunjukan ada 4 faktor yang menunjukan kesiapan tetapi masih membutuhkan sedikit peningkatan yaitu faktor environmental readiness, faktor human resource readiness, faktor financial readiness, faktor content readiness dan ada 4 faktor yang menunjukan tidak siap dan membutuhkan sedikit peningkatan yaitu faktor psychological readiness, faktor sociological readiness, faktor technological skill readiness, faktor equipment readiness. Dan untuk siswa ada 2 faktor yang menunjukan kesiapan tetapi masih membutuhkan sedikit peningkatan yaitu faktor sociological readiness, faktor human resource readiness dan ada 6 faktor yang menunjukan tidak siap dan membutuhkan sedikit peningkatan yaitu faktor psychological readiness, faktor environmental readiness, faktor financial readiness, faktor technological skill readiness, faktor equipment readiness, faktor content readiness. Dari skor total maka sekolah memperoleh skor $x=3,20$, termasuk dalam katagori tidak siap dan membutuhkan sedikit peningkatan.

Diharapkan bagi peneliti selanjutnya agar melakukan penambahan indikator-indikator sebagai komponen pembentuk kuisioner model chapnick dapat dilakukan agar memberikan hasil pengukuran yang lebih optimal sesuai tempat penelitian dan bagi peniliti selanjutnya bisa melakukan penelitan terkait dengan model yang berbeda guna memperoleh perbandingan hasil kesiapan e-learning di sekolah tersebut

\section{DAFTAR PUSTAKA}

[1] R. Indonesia, "Pengelolaan dan Penyelenggara Pendidikan," Pemerintah Republik Indonesia, Indonesia, 2010.

[2] Sugiyono, Metode Penelitian Kuantitatif Kualitatif dan R\&D, Bandung: Alfabeta, 2012.

[3] H. N. Waryanto and N. Insani, "Tingkat Kesiapan (Readiness) implementasi e-learning di Sekolah Menengah Atas kota Yogyakarta.," vol. 1, no. 2, 2013.

[4] R. I. Fariani, "Pengukuran Tingkat Kesiapan E-Learning (E-Learning Readiness)," Seminar Nasional Aplikasi Teknologi Informasi (SNATI), no. 1, pp. 1907-5022, 2013.

[5] H. Siti, "Kajian Implementasi E-learning Berdasarkan Tingkat Kesiapan Peserta E-learning.," vol. 8, 2014.

[6] s. Widiastuti and I. Budi, "Analisis Pengukuran Tingkat Kesiapan Knowledge Management : Studi Kasus Pusat Pengolahan Data dan Informasi Badan Koordinasi Penanaman Modal," 2016.

[7] R. Faslah and H. B. Santoso, "Analisis Kesiapan Implementasi E-learning Menggunakan Elearning Readiness Model.," vol. 3, no. 2, pp. 113-120, 2017.

[8] mahmud, Metode Penelitian Pendidikan, Bandung: Pustaka Setia, 2011.

[9] Arikunto, Prosedur Penelitian Suatu Pendekatan Praktik, Jakarta: Rineka Cipta, 2010.

[10] A. Kurniawan, "Pengukuran Tingkat Kesiapan Penerapan E-learning Sekolah Menengah Atas Muhammadiyah di Yogyakarta," vol. 3, no. 5, 2014. 